\title{
How to preserve a butterfly species within an urbanising settlement and its surroundings: a study of the scarce copper (Lycaena virgaureae $L_{\text {.) }}$ in southern Sweden
}

\author{
Christine Haaland ${ }^{1}$ (I)
}

Received: 10 April 2017 / Accepted: 25 October 2017 / Published online: 2 November 2017

(C) The Author(s) 2017. This article is an open access publication

\begin{abstract}
Urbanisation is a rapidly ongoing process worldwide with profound consequences for wildlife in urban and peri-urban areas. Species are affected by habitat loss, habitat alternation and degradation, fragmentation and increased human population and activity. Habitat loss can occur due to construction of housing and infrastructure in peri-urban areas and within urban areas due to compaction. Undeveloped areas can also be changed from ruderal land, wilderness areas or leftover green space to more formal and more intensively used urban green space. This study investigated a butterfly species, the scarce copper (Lycaena virgaureae L.), in an urbanising and expanding settlement in a rural location in southern Sweden. The scarce copper is still relatively common in Sweden, but has experienced severe decline in certain areas and in other parts of Europe. Patch occupancy and abundance of the species were investigated in 44 patches ranging from urban and peri-urban to rural locations. Habitats investigated were parks, urban grasslands managed for biodiversity by the local authority, unmanaged abandoned arable sites, road verges, meadows and pastures. In total, 624 sightings of scarce coppers were recorded. The highest abundances were observed in larger unmanaged patches and in meadows in peri-urban areas, while pastures had low abundances. In urban parks, no coppers were found. The smaller sites managed for biodiversity by the local authority within the settlement were often occupied by the scarce copper, although abundances were low (mean number of individuals $3 \pm 1.2$ ). In patches which were cut, copper numbers dropped
\end{abstract}

Christine Haaland

christine.haaland@slu.se

Department of Landscape Architecture, Planning and Management, Swedish University of Agricultural Sciences, Box 58, 23053 Alnarp, Sweden in almost all cases to zero after cutting. Patch occupancy was affected by habitat characteristics such vegetation height, tree succession, abundance of Rumex acetosella (sheep's sorrel), as well as landscape features such as length of forest edge. Factors identified as influencing abundance were the same, but additionally also flower abundance. The current high abundances of the scarce copper in the area will not be ensured in the longer term when all building plans are implemented and no other measures are taken. Recommendations are made on management and planning to preserve the species in the study area.

Keywords Grassland $\cdot$ Management $\cdot$ Planning $\cdot$ Patch occupancy · Sweden · Urban fringe · Urban green space · Urbanisation

\section{Introduction}

Urban areas and their surroundings can have high biodiversity regarding animal (e.g. Connor et al. 2002; Jones and Leather 2012; Goertzen and Suhling 2015) and plant species (e.g. Kühn et al. 2004; O'Farrell et al. 2012; Capotorti et al. 2013; Kantsa et al. 2013). Many different factors affecting biodiversity in urban areas have been identified. At local scale, these include vegetation structure, patch area (Beninde et al. 2015), habitat structure (Garden et al. 2010) and management (Shwartz et al. 2013; Beninde et al. 2015; Garbuzov et al. 2015). At landscape scale, landscape structure (Garden et al. 2010), land cover (Aronson et al. 2014), amount of vegetated area (Turrini and Knop 2015) and presence of corridors (Beninde et al. 2015) have been recognised as factors affecting biodiversity. City age has also been mentioned as a factor that influences urban biodiversity (Aronson et al. 2014). Rupprecht et al. (2015) highlight the importance of 
informal green space for biodiversity preservation in urban areas. They found that management, age of green space, distance to city centre and habitat diversity affect biodiversity in these types of green space. Rural-urban gradients have often been studied in the context of urban biodiversity and, according to Beninde et al. (2015), animal diversity tends to decline towards the city centre, while plant species diversity increases. The importance of peri-urban areas for the biodiversity of inner urban areas has been stressed (Snep et al. 2006).

Consequences of urbanisation are habitat loss (e.g. Seto et al. 2012), habitat alternation/degradation (Schochet et al. 2016) and fragmentation (Gibb and Hochuli 2002), which lead to species loss (Buczkowski and Richmond 2012), a decline in species density (Aronson et al. 2014) or a change in species composition (Gibb and Hochuli 2002). Homogenisation of species composition has often been observed in the context of urbanisation (McKinney 2006; Knapp and Wittig 2012) whereby specialists (for butterflies here defined as species with comparatively lower mobility, fewer larval and adult food plants) are often replaced by generalists (Concepción et al. 2015). Peri-urban fringes often experience the most profound changes (New 2015), resulting in negative impacts on biodiversity.

While urban areas have been comparatively well studied regarding their biodiversity patterns, smaller settlements classified as villages and farmsteads have been less frequently investigated. Studies indicate that villages are important in a biodiversity perspective and that urbanisation can cause similar trends as in urban areas. Hiron et al. (2013) and Rosin et al. (2016) showed that farmsteads can be hotspots for bird biodiversity, while the proportion of new houses is negatively correlated with bird biodiversity. Trends such as homogenisation have also been observed (Knapp and Wittig 2012). While effects of urbanisation on biodiversity can have similar trends in peri-urban areas of larger towns compared to settlements in more rural settings, potentially different species can be affected. Knapp et al. (2008) have for example shown that butterfly species richness was significantly higher in rural protected areas than in urban and peri-urban protected areas.

Butterflies are a comparatively well-studied species group in urban areas (Ramírez-Restrepo and MacGregorFors 2017). Local or habitat factors that have been identified as affecting butterfly diversity in an urban context are habitat type (e.g. Öckinger et al. 2009; Matsumoto 2015), patch area (Öckinger et al. 2009; Shwartz et al. 2013), management practices such as cutting height, pesticide use or quantity of mulch (Shwartz et al. 2013) and habitat quality (Shwartz et al. 2013; Lizee et al. 2016). Butterfly species richness in urban areas is often found to be related to landscape factors such as total green area (Öckinger et al. 2009), grassland area (Lizee et al. 2016), natural vegetation cover
(Chong et al. 2014), habitat diversity (Dallimer et al. 2012), fragmentation (Öckinger et al. 2009), degree of isolation and matrix configuration (defined as shape complexity of matrix patches; Lizée et al. 2012). Most butterfly studies have found a negative correlation between butterfly species richness and urbanisation (Casner et al. 2014; Fontaine et al. 2016; Ramírez-Restrepo and MacGregor-Fors 2017). This study here is a follow-up to a previous one which found that a butterfly species, the scarce copper (Lycaena virgaureae L.), occurred in high abundances at the southern fringe of a settlement in southern Sweden (Haaland 2015). Large areas around the settlement were zoned for housing development at that time. Construction has now started in some of these areas and questions addressed in the present study, conducted in a larger study area, were:

If these habitats at the settlement fringe disappear due to urbanisation, are there other suitable habitat patches in the wider area where the scarce copper is present?

What are the habitat requirements of the species, including an urban context?

What recommendations can be given regarding management and planning to allow the scarce copper to survive in high abundances in the area?

The findings were discussed in the context of existing literature on butterfly conservation in urban areas including the question whether any conservation measurements should be considered for an unthreatened butterfly species in an urban/ peri-urban context. In this regard, some of the motivations identified by Dearborn and Kark (2009) can be relevant to this butterfly assessment. These include: the preservation of local biodiversity, educational reasons, improving wellbeing and ethical responsibility.

\section{Methods}

\section{Study area}

The study area is located in and around the settlement of Veberöd (Lund municipality) in Scania, the most southerly province of Sweden. Veberöd is situated $30 \mathrm{~km}$ east of Malmö, Sweden's third largest city and is an expanding settlement, currently with about 5000 inhabitants, in commuting distance (30 $\mathrm{min}$ ) to Malmö. The study area comprised around 900 ha. The surroundings of Veberöd are characterised by agricultural land and woodlands. Agricultural land includes both arable land and semi-natural pastures, which is the dominant grassland type. Several of the semi-natural pastures included in the study are nature reserves. Semi-natural meadows with long continuity are absent. The areas classified as meadows in this study are areas with predominantly 
grass and herbal vegetation. Vegetation is cut here once a year, for conservation, subsidy or amenity reasons. These areas, which have some meadow characteristic regarding their vegetation and management, have been previously used as arable land. The soils in the area are sandy and therefore agriculture has not been carried out in its most intensive forms.

Veberöd consists primarily of single-family houses. It expanded greatly during the 1970s when planning followed the typical Swedish pattern of the time of a spacious layout for green infrastructure, including small parks and other green space. At the northern fringe an industrial area has been established, but it is still interwoven with abandoned farmland where some secondary succession is taking place. Here, and in one area south of the settlement, the local authority (municipality of Lund) manages some areas for biodiversity conservation, with the focus on insects with a habitat on sandy soils. These areas on sandy soils are particular species rich in the region, but have decreased due to land use changes as afforestation and agricultural intensification. Farms with agricultural production are few and situated at the fringe of the settlement. At the moment, Veberöd is experiencing another phase of urban expansion. According to the comprehensive plan for Lund's municipality, the number of housing units is to double by 2050, with 1000 new housing units planned in the first phase of construction (Lunds kommun 2010). The development plans involve the fringe on farmland, abandoned farmland and forest, but also include densification projects within the existing settlement boundary on, for example, abandoned farmland, green space and urban forest.

\section{The species}

The habitat of the scarce copper ( $L$. virgaureae L.) in Scandinavia is typically extensively used grasslands near forest and woodlands. It can be especially abundant in flowerrich meadows (Henriksen and Kreutzer 1982; Ohlsson and Wedelin 2012) and occurs both in the lowlands and in mountain regions. Sheep's sorrel (Rumex acetosella) and common sorrel (Rumex acetosa) are most often cited as larval host plants (Schlumprecht and Bräu 2013) though other Rumex species, such as $R$. thyrsiflorus, have also been mentioned (Bink 1992 cited in Schlumprecht and Bräu 2013).

The scarce copper is not an uncommon species in Sweden, but has experienced severe declines in certain regions (Öckinger et al. 2006; Nilsson et al. 2008, 2013). A striking finding by Nilsson et al. (2008, 2013) when comparing sites between different time periods is that the scarce copper has declined from being both common and numerous to being not present or nearly vanished. Öckinger et al. (2006) recorded seven extinctions and no colonisation when comparing surveys of 12 sites in Scania performed in 1980-1982 and 2002-2003. No other species experienced a worse decline in that study (but some species showed a similar decline). In other regions in Sweden, the scarce copper is still frequently occurring in pastures (Franzén and Ranius 2004).

While this study here was carried out in a lowland region the scarce copper occurs in certain mountainous regions in other parts of Europe, for example in the Pyrenees, Massif Central, the Alps, and in Scandinavia (Tolman and Lewington 1997). In some areas its distribution is described as localised and declines in distribution have been observed, for example in Bavaria (Schlumprecht and Bräu 2013) and in Baden-Württemberg (Ebert 1991). The reasons for the decline are not entirely clear, but possible factors are habitat loss (Ebert 1991; Schlumprecht and Bräu 2013), climate change (Schlumprecht and Bräu 2013) and change in habitat quality (Öckinger et al. 2006; Nilsson et al. 2013).

\section{Butterfly recording}

Butterfly recordings were carried out on 44 patches, four times on each patch, between the 23 July and 21 August 2015. Two small patches (northern fringe, industrial area) were visited only three times (missed on the first recording visit). The total patch area was approximately 63 ha (Table 1).

Butterfly recordings were only performed under good weather conditions (Pollard and Yates 1993) and between 10.00 and $17.00 \mathrm{~h}$. During recording, the patches were walked systematically and all butterfly individuals were recorded, distinguishing between males and females.

\section{Patch characteristics}

Patches included in this study, represented different types of habitats with grass vegetation. The studied patches were situated within the settlement, in the peri-urban fringe and in the surrounding countryside. All patches included in the mark-release-recapture study by Haaland (2015) were included. One of these patches had considerably smaller area than in 2015 as it had been partly built on. Another patch had been converted into a dog training field, therefore an adjacent area of about same habitat quality and size was studied instead.

The different habitats investigated were: urban parks, pastures, meadows, areas managed for biodiversity by the local authority, road verges and unmanaged areas (Table 1). One private garden was included, since it was part of the previous study (Haaland 2015). These habitat types represent a gradient in management intensity from high to low regarding frequency in cutting or grazing intensity for pastures. 
Table 1 Habitat type and patch area of investigated patches

\begin{tabular}{lcclllr}
\hline Habitat & $\begin{array}{l}\text { Number of } \\
\text { patches }\end{array}$ & $\begin{array}{l}\text { Patch area total } \\
\text { (ha) }\end{array}$ & $\begin{array}{l}\text { Patch area mini- } \\
\text { mum (ha) }\end{array}$ & $\begin{array}{l}\text { Patch area maxi- } \\
\text { mum (ha) }\end{array}$ & $\begin{array}{l}\text { Mean patch area (ha) } \\
\text { of total } \\
\text { area sur- } \\
\text { veyed }\end{array}$ \\
\hline Unmanaged grassland & 15 & 13.4 & 0.04 & 3.32 & 0.90 (StD 0.95) \\
Road verges & 5 & 0.9 & 0.02 & 0.49 & 0.18 (StD 0.19) \\
Biodiversity areas & 6 & 3.6 & 0.09 & 1.08 & 0.61 (StD 0.40) \\
Meadows & 3 & 19.0 & 0.93 & 9.04 & 6.33 (StD 4.68) \\
Pastures & 5 & 19.5 & 1.60 & 8.69 & 3.91 (StD 2.76) & 30 \\
Parks & 9 & 6.7 & 0.34 & 1.44 & 0.75 (StD 0.40) \\
Garden & 1 & 0.04 & 0.36 & 0.36 & & 11 \\
Total & 44 & 63.14 & & & & 0 \\
\hline
\end{tabular}

StD standard deviation

- Unmanaged: no cuttings.

- Road verges: either uncut or only partly cut leaving uncut vegetation.

- Biodiversity areas: cut once in middle of August, once a year.

- Meadows: cut once a year at the beginning of August.

- Pasture: grazed most often during the study period, sometimes before and/or after.

- Parks: cut several times during the study period.

- Garden: flowerbeds, lawn cut several times during the study period.

Besides habitat type, the following characteristics for each patch were recorded:

- Vegetation height in three classes (1-3), where 1: up to $20 \mathrm{~cm}, 2: 20-50 \mathrm{~cm}, 3$ : above $50 \mathrm{~cm}$.

- Flower abundance in three classes (1-3), where: 1: low flower abundance, 2 : intermediate flower abundance, 3 : high flower abundance.

- Abundance of the potential larval food plants $R$. acetosa, $R$. acetosella and $R$. thyrsiflorus in four classes (0-3) for each species separately where: 0:absent, 1 : low abundance, 2: medium abundance, 3: high abundance of respective Rumex species.

- Tree succession in four classes (0-3) where: 0: no sign of tree succession, no visible tree seedlings, 1 : few signs of tree succession, few tree seedlings of a maximum height of $30 \mathrm{~cm}, 2$ : tree succession abundant, young trees above $30 \mathrm{~cm}, 3$ : tree succession abundant, later stage of succession with trees above $2 \mathrm{~m}$.

These characteristics were recorded only on the first survey occasion except for height, which was recorded on all survey occasions.
In addition, the following spatial characteristics were taken from geographic information system (GIS) (ArcMap, 10.4.1, ESRI 2015):

- Area.

- Length of forest edge (in all but one case the forest edge formed the patch boundary or part of it; the exception was one large pasture which included grazed, half-open woodlands, here the forest edge did not form the patch boundary).

- Mean distance to the five nearest patches (edge to edge).

\section{Statistical analysis}

For the statistical analysis, the software SAS (SAS 9.4) was used. Factors influencing patch occupancy of the scarce copper were analysed using logistic regression in SAS with PROC GLIMMIX. The model used observations within the patch as repeated measures with correlation structure compound symmetry and the variables were included in a stepwise procedure using forward selection.

For the analysis of abundance, the observations were transformed using the transformation $\ln ($ abundance +1 ), and after this transformation the observations satisfied the assumption of normality. In the analysis, SAS with PROC MIXED were used with patch as random factor. The variables were included in a stepwise procedure using forward selection.

\section{Results}

\section{Area and habitat type of surveyed patches}

Most of the patches investigated were unmanaged grassland areas (within and at the periphery of the settlement) 
and parks (Table 1). The numbers of meadows and pastures were low, but they comprised almost two-thirds of the study area, since their area was larger than that of the other habitat types. The areas managed by the local authority for biodiversity goals and the road verges had the smallest mean area (Table 1).

\section{Patch occupancy}

In total, 624 individuals of the scarce copper butterfly were observed during the study period, of which 398 were males and 226 (36\%) females. Of the 44 patches studied, 13 (30\%) were occupied on all four recording occasions and 18 patches $(40 \%)$ were occupied on at least one occasion (Fig. 1). In 13 patches, no scarce coppers were observed on any recording occasion (Fig. 1). In parks, not a single scarce copper was observed on any of the survey occasions. Of the 13 patches that were occupied on all four occasions, unmanaged patches were in the majority. The biodiversity areas managed by the local authority were all occupied at least once, most often 2-3 times.

Factors that influenced patch occupancy were vegetation height, the abundance of $R$. acetosella, time of survey, tree succession and length of forest edge (Table 2). Factors showing no significant differences between occupied (at least once) and unoccupied patches were flower abundance and the abundance of $R$. acetosa and $R$. thyrsiflorus, and
Table 2 Factors influencing patch occupancy by the scarce copper butterfly; results for the logistic regression (stepwise forward)

\begin{tabular}{lrl}
\hline Variable & $\mathrm{F}$ & $\mathrm{p}$ Value \\
\hline Vegetation height & 14.50 & $0.0002^{* * *}$ \\
Rumex acetosella & 8.98 & $0.0046^{* *}$ \\
Time of survey & 4.91 & $0.0029^{* *}$ \\
Tree succession & 5.69 & $0.0218^{*}$ \\
Length of forest edge & 6.14 & $0.0175^{*}$ \\
Area & 3.24 & 0.0798 n.s. \\
Flower abundance & 2.65 & 0.1121 n.s. \\
Rumex acetosa & 2.44 & 0.1264 n.s. \\
Mean distance to five nearest & 0.40 & 0.5304 n.s. \\
patches & & \\
Rumex thyrsiflorus & 0.07 & 0.7903 n.s. \\
\hline
\end{tabular}

$* \mathrm{p}<0.05 ; * * \mathrm{p}<0.01 ; * * * \mathrm{p}<0.001 ;$ n.s. $\mathrm{p}>0.05$

the spatial variables area and mean distance to the five nearest patches.

\section{Abundances}

Factors significantly explaining variation in scarce copper abundances between patches were tree succession, the abundance of $R$. acetosella, the length of forest edge, time of survey, flower abundance and vegetation height (Table 3). Variables that were included in the analysis, but did not
Fig. 1 Patch occupancy of the scarce copper (Lycaena virgaureae) butterfly in the study area, Veberöd, Lund municipality, Scania, Sweden. Number of patches surveyed was 44 . (Color figue online)

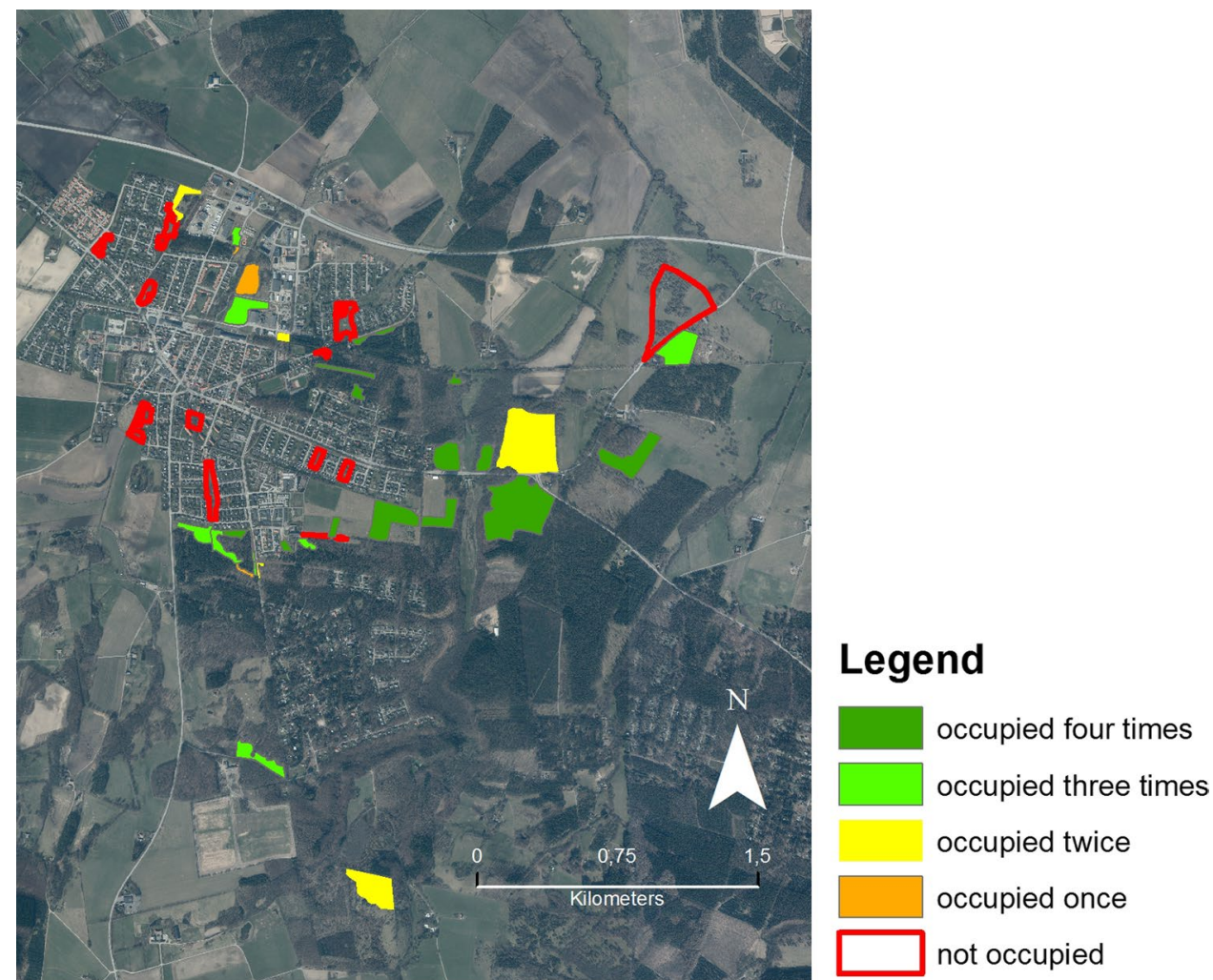


significantly explain variations in abundances were the abundance of the two other Rumex species recorded and the spatial variables area and mean distance to the five nearest patches (Table 3).

Figure 2 shows habitat type and scarce copper abundance (red charts) within the studied patches. As can be seen from the figure, there were greater numbers of scarce coppers in the south-eastern part of the study area, in meadows and unmanaged areas. The pastures situated farthest away from the settlement supported only small numbers of the butterfly, apart from one pasture that was grazed later in the season, after the end of the study period (and perhaps very early in the season). The species was found in smaller abundances throughout the settlement in unmanaged areas, road verges and the areas managed for biodiversity but, as mentioned, not in the parks.

\section{Influence of mowing on abundances}

During the field work, it was observed that abundances were very much affected by mowing, decreasing drastically after mowing (Fig. 3). In the meadow with the highest abundances on the first survey occasion, 86 scarce copper were found (36 males, 50 females). On the second occasion three individuals were found and on the third and fourth occasions no individuals were found. The scarce coppers that were found after mowing were often confined to the outer patch boundary where the vegetation was not cut. In the biodiversity areas, after mowing only one single scarce copper was found on the fourth recording occasion in all patches. The declining number of individuals in the unmanaged parts (Fig. 3) was due to seasonal effects. At the end of August, almost all scarce coppers were found in the unmanaged patches.

Table 3 Factors explaining variation in abundance of scarce copper butterflies between patches; results of the mixed model analysis (stepwise forward)

\begin{tabular}{lrrrc}
\hline Variable & AIC & \multicolumn{1}{l}{ F } & p & $\begin{array}{l}\text { Variables } \\
\text { included }\end{array}$ \\
\hline Tree succession & 467.0 & 42.48 & $<0.0001^{* * *}$ & 1 \\
Rumex acetosella & 436.1 & 38.21 & $<0.0001^{* * *}$ & 2 \\
Length forest edge & 428.6 & 23.94 & $<0.0001^{* * *}$ & 3 \\
Time of survey & 413.9 & 7.35 & $0.0001^{* * *}$ & 4 \\
Flower abundance & 405.6 & 11.00 & $0.0011^{* *}$ & 5 \\
Vegetation height & 403.7 & 4.90 & $0.0283^{*}$ & 6 \\
Rumex acetosa & 402.0 & 2.35 & 0.1274 n.s. & 7 \\
Rumex thyrsiflorus & 403.3 & 1.93 & 0.1671 n.s. & 8 \\
Area & 407.7 & 0.63 & 0.4302 n.s. & 9 \\
Mean distance to & 422.2 & 0.26 & 0.6137 n.s. & 10 \\
five nearest patches & & & & \\
\hline
\end{tabular}

$* \mathrm{p}<0.05 ; * * \mathrm{p}<0.01 ; * *$ p $<0.001 ;$ n.s. $\mathrm{p}>0.05$

\section{Effect of planned housing development}

The planned housing development (Fig. 4) will eradicate some of the most important habitats of the scarce copper, namely the unmanaged areas at the south-eastern fringe of the settlement. This process has already started. In addition, a few smaller patches in the forested area will be lost (north-east of the settlement). The larger unmanaged patches (in total 5.3 ha) within the northern part of the settlement were ploughed in 2016 (but not in connection with housing development) and sown, partly with sunflowers and partly with another species mixture. In both cases, the patches are no longer a suitable habitat for the scarce copper.

\section{Discussion}

\section{Habitat requirements}

This study showed that the scarce copper is more often present in habitat patches with high vegetation and less intensive management than in areas with a short grass sward and more intensive management. The species was predominantly found in unmanaged grassland habitats or habitats that are only cut once a year (meadows, certain road verges, biodiversity areas) and was absent from pastures with a short grass sward and from all parks investigated. This is in line with findings that suggest urban green spaces with less intensive management have higher species richness of butterflies (e.g. Öckinger et al. 2009; Garbuzov et al. 2015). It also supports findings by Lizée et al. (2011) that the highest butterfly diversity in an urbanising area in France was on fallow land. The negative impact of mowing on butterfly abundance has been pointed out in previous studies (e.g. Dover et al. 2010). A more striking finding in the present study was the scale of the impact on the scarce copper. These results emphasise the importance of informal green space in urban areas, as stated for example by Rupprecht et al. (2015), and the provision of uncut areas for butterflies in agricultural areas (Lebeau et al. 2015). It is interesting to note, however, that although the scarce copper was present in most pastures, abundances were usually low.

This study confirmed scarce copper habitat preferences reported previously, such as a certain affinity to forest edges and high flower abundance (e.g. Douwes 1975; Barua et al. 2011). A new finding was the positive correlation of tree succession with both occupancy and abundance. It should be noted that tree succession up to a certain degree (as examined in this study) is positively correlated with both flower abundance and vegetation height. Additionally the scarce copper might benefit from shelter provided by young trees. However, in areas where tree succession has gone further, so that the canopy cover is closing and permanently shading 
Fig. 2 Land use and abundances of the scarce copper butterfly (Lycaena virgaureae) in 44 patches in the study area, Veberöd, Lund municipality, Scania, Sweden. Total number of butterflies observed was 624 . Height of column indicates number of individuals found during study period. (Two patches in the south of the study area with few individuals observed were omitted form the map for better visibility of the rest of the study area)

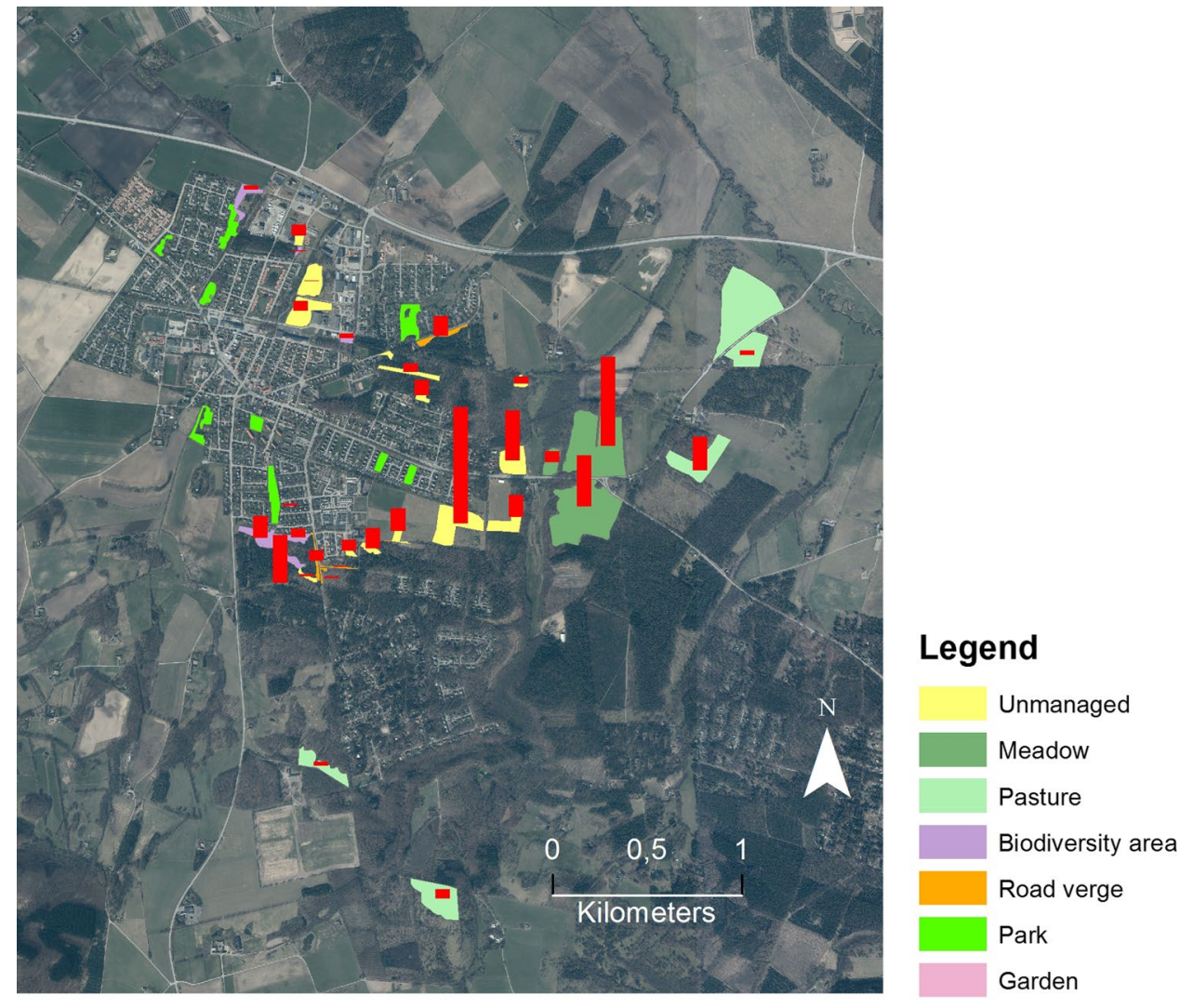

ground layer vegetation, the scarce copper will be negatively affected.

One of the larval food plants, $R$. acetosella, was found to explain differences in occupancy and abundances between patches. However, no relationship between any other Rumex species recorded and occupancy or abundances was observed. It can be added that, for example in the parks, at least one of the Rumex species, including $R$. acetosella, was often abundantly present, but these Rumex plants were all very short (lawn height) and probably not sufficient as a larval habitat. In order to explain the habitat requirements of the species in greater detail, the requirements for larval habitat would need to be investigated regarding for example host plant characteristics and tolerance to management.

As mentioned in the introduction, the study was carried out in an area dominated by sandy soils. Thus the majority of the habitat patches had dry vegetation, most others fresh conditions and only two patches had wet conditions. Thus the reported affinity of the scarce copper for wet grasslands (e.g. Henriksen and Kreutzer 1982) was not confirmed in the study area, where high abundances occurred in areas with dry vegetation.

Besides length of forest edge, no other spatial factor as patch area or connectivity measured in distance to the five nearest patches, showed significant effects on occupancy or abundance. The mobility of the species appears to be good enough to colonise suitable patches within the existing network as could be shown previously in a part of the study area (Haaland 2015).

Time of survey affected both occupancy and abundances due to seasonal effects and cutting regime.

\section{Spatial distribution within the study area}

The highest abundances of scarce coppers were found in the south-eastern part of the study area. The highest abundance in a single patch recorded at one occasion was 86 individuals and was observed in this part of the study area.

The pastures on the outskirts of the settlement studied here did not support larger abundances of scarce coppers than the unmanaged land and meadows at the periphery. Several of the pastures were nature reserves or part of Natura 2000 reserves, thus involving partly extensive forms of grazing. Thus land-use changes leading to the loss of the unmanaged and/or meadow areas will lead to the loss of those habitat patches with the highest abundances of the scarce copper. Areas with few individuals of the scarce copper, including pastures, have previously been shown to be prone to extinction (Ebert 1991; Öckinger et al. 2006). Consequently, survival of the species in areas that today are protected by nature conservation legislation within the study area is not guaranteed. 


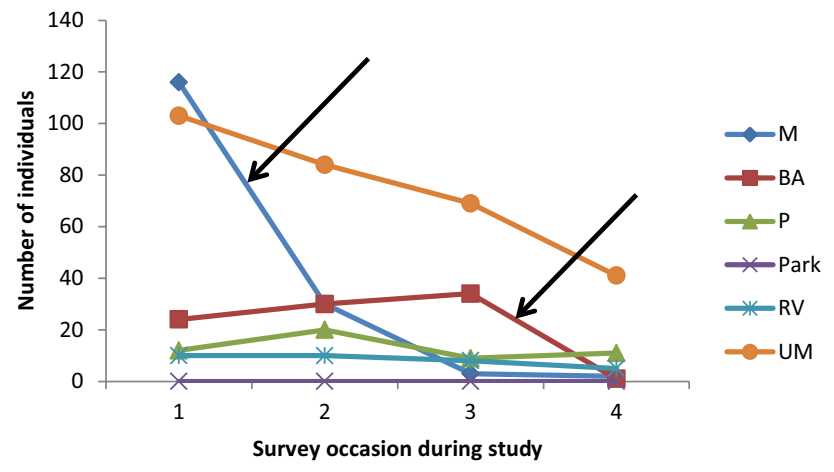

Fig. 3 Effect of mowing on abundances of the scarce copper butterfly in different habitat types. Note that the area of the different habitat types surveyed differed greatly (see also Table 1). Arrows indicate time of mowing event: between first and second survey for meadows (M), between third and fourth survey for areas managed for biodiversity by the local authority (BA). Parks were continuously mown. M: meadow (30\% of surveyed area), BA: areas managed for biodiversity by the local authority $(6 \%)$, P: pasture $(31 \%)$, Park (11\%), RV: road verge (1\%), UM: unmanaged grassland (21\%)

A positive finding was that the scarce copper was present in all areas managed for biodiversity by the local authority. This means that these areas are successful in providing a habitat for the species. However, the biodiversity areas within the settlement are small and therefore the total number of individuals found here was low. Nevertheless, the network of small patches of unmanaged land, the biodiversity areas and road verges with extensive management have ensured that the species is still occurring within the settlement area. This is remarkable, since the species is virtually absent in areas in the region previously known for their high butterfly diversity (Öckinger et al. 2006; Nilsson et al. 2013). The results of the present study also clearly demonstrate that current parks are not a substitute habitat if other habitats vanish. However, it is more doubtful whether the scarce copper can survive within the settlement in the long term by relying on the small existing and occupied habitat patches at the southern fringe of the settlement.

\section{Implications for management and planning}

The most important measure to ensure the long-term survival of the species in the study area would be to preserve the large patches east of the settlement. This would include two meadows and one unmanaged patch without any building plans. Here, a management form suitable for the species should be applied: late cutting in the season (September), applying rotational cutting of different parts during years and leaving wide margins at the edges. However, the margins would need cutting eventually to prevent habitat loss due to succession in the long-term. Overall, rotational mowing would be needed to prevent long-term successional vegetation changes to woodland vegetation, which is disadvantageous for the scarce copper and many other grassland butterfly species. Cutting height should be practiced as is done in the areas currently managed for biodiversity by the local authority, where cutting height is much higher than in the parks and which seems to be appropriate for the scarce copper. Preserving these peri-urban areas would very
Fig. 4 Planned and ongoing housing development in the study area, Veberöd, Lund municipality, Scania, Sweden. Based on Lund municipality's comprehensive plan (Lunds kommun 2010). Red: planned and ongoing housing development, yellow: investigated patches. Arrows mark patches with high scarce copper abundances outside nature reserves, where it would be important to implement a long-term management beneficial to the species. (Color figue online)

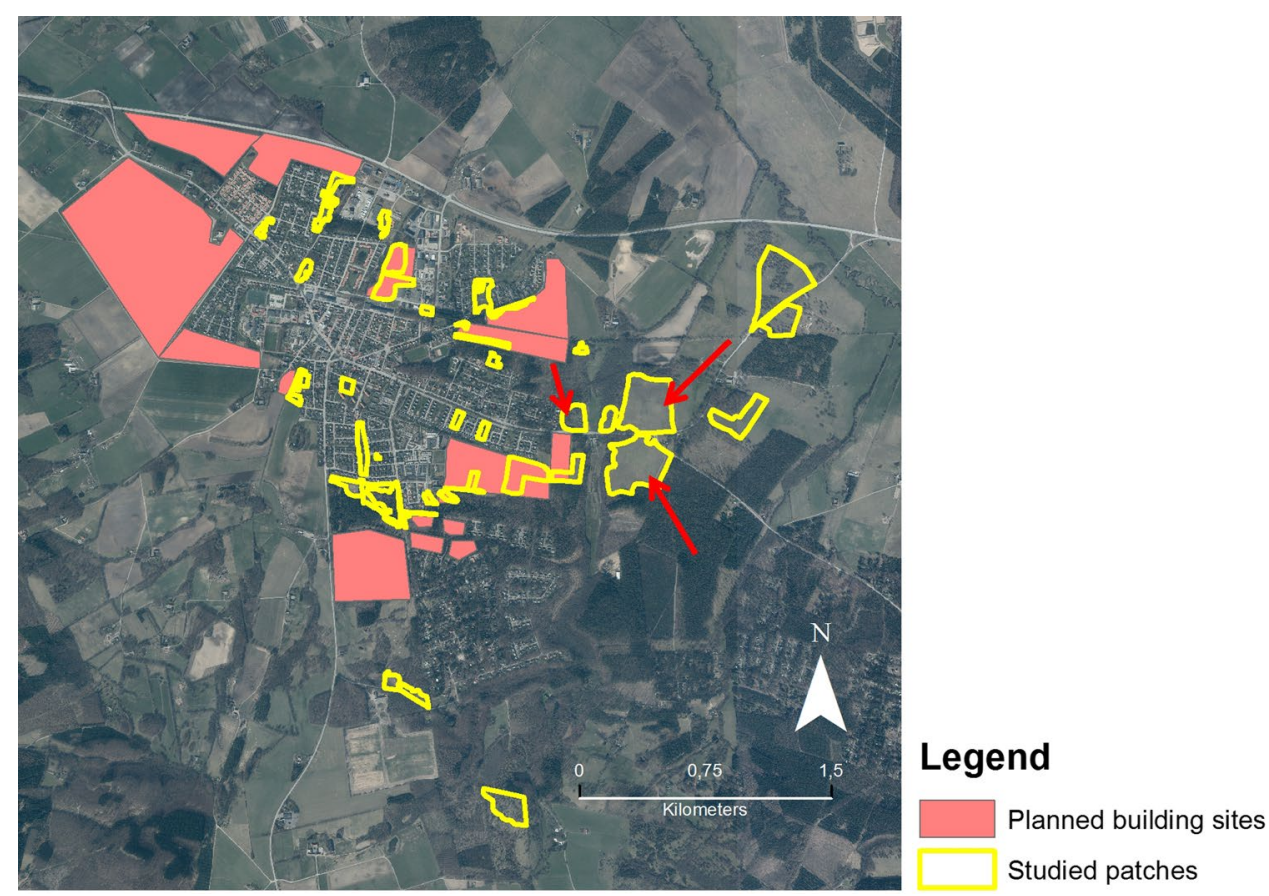


likely positively influence abundances of the scarce copper within the settlement (Snep et al. 2006). This is partly supported by reports of movements from the periphery to a garden (Haaland 2015).

The most important areas addressed here were classified as meadows, since the management was mowing and the vegetation resembled meadow vegetation. However, these areas were previously used as arable land and are probably only mown to meet the requirements for subsidies within agri-environmental schemes for fallow land. Thus there is a risk that these areas could be ploughed up again as soon as farm management or ownership changes.

Finally, the areas managed for biodiversity goals by the local authority should be preserved as such. They benefit the scarce copper and would allow people to observe the species close to their home(information boards inform about the existence of the scarce copper and other species living in areas of sandy soils). An even later cutting date could be considered. It is also important to leave the unmanaged areas within and around the settlement unmanaged. This would not only benefit the scarce copper and other butterfly species, but urban biodiversity in general (Rupprecht et al. 2015).

\section{Why concern for an unthreatened butterfly species in an urban/peri-urban context?}

The occurrence of a single butterfly species will rarely be relevant in a legal planning context regarding development projects in the region of Scania. Of the ten butterfly species protected according to Swedish law (based also on the EU habitat directive), only one occurs in the region of Scania the large blue, Phengaris arion, which has near threatened status in Sweden (ArtDatabanken 2015). Three of the protected butterfly species do not have their geographical distribution in Scania and six became extinct in the region between the 1950s and 1980s.

In the case of the scarce copper, the preservation of local biodiversity can be seen as a relevant argument for conservation measurement for an unthreatened species in an urban/ peri-urban context (see Dearborn and Kark 2009). It could be aimed for to keep homogenisation caused by urbanisation (McKinney 2006) at a minimum. Educational incentives are supported by the local authority's information signs in the areas managed for biodiversity and the guided walks it offers. The improvement of well-being through wildlife observations can certainly be relevant for some inhabitants, but debatable for others (those irritated by lack of intensive management of urban green space). However, according to a study by Garbuzov et al. (2015), the proportion of people who perceive reduced management as purely negative is rather low. Regarding the scarce copper, there are two other aspects to consider: peri-urban areas seem to be a more suitable habitat than much of the surrounding agricultural landscape, even areas protected as a nature reserve, and abundances seem to be particularly high in peri-urban areas even in a regional perspective.

Acknowledgements This study was funded by the Swedish University of Agricultural Sciences (SLU), Department of Landscape Architecture, Planning and Management, Alnarp. I am thankful to Jan-Eric Englund for help with the statistics and Mary McAfee, who corrected the English.

\section{Compliance with ethical standards}

Conflict of interest The author declares that she has no conflict of interest.

Open Access This article is distributed under the terms of the Creative Commons Attribution 4.0 International License (http://creativecommons.org/licenses/by/4.0/), which permits unrestricted use, distribution, and reproduction in any medium, provided you give appropriate credit to the original author(s) and the source, provide a link to the Creative Commons license, and indicate if changes were made.

\section{References}

Aronson MFJ, La Sorte FA, Nilon CH, Katti M, Goddard MA, Lepczyk CA, Warren PS, Williams NS, Cilliers S, Clarkson B, Dobbs C, Dolan R, Hedblom M, Klotz S, Kooijmans JL, Kühn I, Macgregor-Fors I, McDonnell M, Mörtberg U, Pysek P, Siebert S, Sushinsky J, Werner P, Winter M (2014) A global analysis of the impacts of urbanization on bird and plant diversity reveals key anthropogenic drivers. Proc R Soc B 281:20133330

ArtDatabanken (2015) Rödlistade arter i Sverige [Red listed species in Sweden]. ArtDatabanken SLU, Uppsala

Barua KK, Chuluunbaatar G, Muehlenberg M (2011) Population structure and mobility of the Scarce Copper Lycaena virgaureae in the herb meadow habitat of Northern Mongolia. J Entomol $8: 40-51$

Beninde J, Veith M, Hochkirch A (2015) Biodiversity in cities needs space: a meta-analysis of factors determining intra-urban biodiversity variation. Ecol Lett 18:581-592

Buczkowski G, Richmond DS (2012) The effect of urbanization on ant abundance and diversity: a temporal examination of factors affecting biodiversity. PLoS ONE 7(8):e41729

Capotorti G, Del Vico E, Lattanzi E, Tilia A, Celesti-Grapow L (2013) Exploring biodiversity in a metropolitan area in the Mediterranean region: the urban and suburban flora of Rome (Italy). Plant Biosyst 147(1):174-185

Casner KL, Forister ML, O'Brien JM, Thorne J, Waetjen D, Shapiro AM (2014) Contribution of urban expansion and a changing climate to decline of a butterfly fauna. Conserv Biol 28(3):773-782

Chong KY, Teo S, Kurukulasuriya B, Chung YF, Rajathurai S, Tan HTW (2014) Not all green is as good: different effects of the natural and cultivated components of urban vegetation on bird and butterfly diversity. Biol Conserv 171:299-309

Concepción ED, Moretti M, Altermatt F, Nobis MP, Obrist MK (2015) Impacts of urbanisation on biodiversity: the role of species mobility, degree of specialisation and spatial scale. Oikos $124: 1571-1582$ 
Connor EF, Hafernik J, Levy J, Moore VL, Rickman JK (2002) Insect conservation in an urban biodiversity hotspot: the San Francisco Bay Area. J Insect Conserv 6(4):247-259

Dallimer M, Rouquette JR, Skinner AMJ, Armsworth PR, Maltby LM, Warren PH, Gaston KJ (2012) Contrasting patterns in species richness of birds, butterflies and plants along riparian corridors in an urban landscape. Divers Distrib 18:742-753

Dearborn DC, Kark S (2009) Motivations for conserving urban biodiversity. Conserv Biol 24(2):432-440

Douwes P (1975) Territorial behaviour in Heodes virgaureae L. (Lep., Lycaenidae) with particular reference to visual stimuli. Norw J Entomol 22:143-154

Dover JW, Rescia A, Fungarino S, Fairburn J, Carey P, Lunt P, Dennis RLH, Dover CJ (2010) Can hay harvesting detrimentally affect adult butterfly abundance? J Insect Conserv 14(4):413-418

Ebert G (ed) (1991) Die Schmetterlinge Baden-Württembergs, Band 2 Tagfalter II. Eugen Ulmer, Stuttgart

ESRI (2015) ArcGIS Desktop: release 10.4.1. Environmental Systems Research Institute. ESRI, Redlands

Fontaine B, Bergerot B, Le Viol I, Julliard R (2016) Impact of urbanization and gardening practices on common butterfly communities in France. Ecol Evol 6:8174-8180

Franzén M, Ranius T (2004) Occurrence patterns of butterflies (Rhopalocera) in semi-natural pastures in southeastern Sweden. J Nat Conserv 12(2):121-135

Garbuzov M, Fensome KA, Ratnieks FLW (2015) Public approval plus more wildlife: twin benefits of reduced mowing of amenity grass in a suburban public park in Saltdean, UK. Insect Conserv Divers 8:107-119

Garden JG, McAlpine CA, Possingham HP (2010) Multi-scaled habitat considerations for conserving urban biodiversity: native reptiles and small mammals in Brisbane, Australia. Landscape Ecol 25:1013-1028

Gibb H, Hochuli DF (2002) Habitat fragmentation in an urban environment: large and small fragments support different arthropod assemblages. Biol Conserv 106:91-100

Goertzen D, Suhling F (2015) Central European cities maintain substantial dragonfly species richness-a chance for biodiversity conservation? Insect Conserv Divers 8:238-246

Haaland C (2015) Abundances and movement of the Scarce Copper Butterfly (Lycaena virgaureae L.) on future building sites at a settlement fringe in southern Sweden. J Insect Conserv 19:255-264

Henriksen HJ, Kreutzer I (1982) The butterflies of Scandinavia in nature. Skandinavisk bogforlag, Odense

Hiron M, Berg Å, Eggers S, Pärt T (2013) Are farmsteads over-looked biodiversity hotspots in intensive agricultural ecosystems? Biol Conserv 159:332-342

Jones EL, Leather SR (2012) Invertebrates in urban areas: a review. Eur J Entomol 109:463-478

Kantsa A, Tscheulin T, Junker RR, Petanidou T, Kokkini S (2013) Urban biodiversity hotspots wait to get discovered: the example of the city of Ioannina, NW Greece. Landscape Urban Plan 120:129-137

Knapp S, Wittig R (2012) An analysis of temporal homogenisation and differentiation in Central European village floras. Basic Appl Ecol 13:319-327

Knapp S, Kühn I, Mosbrugger V, Klotz S (2008) Do protected areas in urban and rural landscapes differ in species diversity? Biodivers Conserv 17:1595-1612

Kühn I, Brandl R, Klotz S (2004) The flora of German cities is naturally species rich. Evol Ecol Res 6:749-764

Lebeau J, Wesselingh RA, Van Dyck H (2015) Butterfly density and behaviour in uncut hay meadow strips: behavioural ecological consequences of an agri-environmental scheme. PLoS ONE 10(8):e0134945
Lizee M-H, Tatoni T, Deschamps-Cottin M (2016) Nested patterns in urban butterfly species assemblages: respective roles of plot management, park layout and landscape features. Urban Ecosyst 19:205-224

Lizée MH, Bonardo R, Mauffrey JF, Bertaudiere-Montes V, Tatoni T, Deschamps-Cottin M (2011) Relative importance of habitat and landscape scales on butterfly communities of urbanizing areas. CR Biol 334(1):74-84

Lizée MH, Manel S, Mauffrey JF, Tatoni T, Deschamps-Cottin M (2012) Matrix configuration and patch isolation influences override the species-area relationship for urban butterfly communities. Landscape Ecol 27(2):159-169

Lunds kommun (2010) Översiktsplan för Lunds kommun [Comprehensive plan for Lund municipality]. Lunds kommun, Lund

Matsumoto K (2015) Habitat specificity of butterflies along urban environmental gradients in Tama City, Tokyo. Entomol Sci 18:509-518

McKinney ML (2006) Urbanization as a major cause of biotic homogenization. Biol Conserv 127:247-260

New T (2015) Insect conservation and urban environment. Springer, Cham

Nilsson SG, Franzén M, Jönsson E (2008) Long-term land-use changes and extinction of specialised butterflies. Insect Conserv Divers 1:197-207

Nilsson SG, Franzén M, Pettersson LB (2013) Land-use changes, farm management and the decline of butterflies associated with seminatural grasslands in southern Sweden. Nat Conserv 6:31-48

O'Farrell PJ, Anderson PML, Le Maitre DC, Holmes PM (2012) Insights and opportunities offered by a rapid ecosystem service assessment in promoting a conservation agenda in an urban biodiversity hotspot. Ecol Soc 17(3):27

Öckinger E, Hammarstedt O, Nilsson SG, Smith HG (2006) The relationship between local extinctions of grassland butterflies and increased soil nitrogen levels. Biol Conserv 128:564-573

Öckinger E, Dannestam A, Smith HG (2009) The importance of fragmentation and habitat quality of urban grasslands for butterfly diversity. Landscape Urban Plan 93:31-37

Ohlsson A, Wedelin M (2012) Dagfjärilar i Skåne 2001-2010 [Butterflies in Scania 2001-2010]. Entomologiska Sällskapet, Lund

Pollard E, Yates TJ (1993) Monitoring butterflies for ecology and conservation. Chapman \& Hall, London

Ramírez-Restrepo L, MacGregor-Fors I (2017) Butterflies in the city: a review of urban diurnal Lepidoptera. Urban Ecosyst 20(1):171-182

Rosin ZM, Skorka P, Pärt T, Zmihorski M, Ekner-Grzyb A, Kwiecinski Z, Tryjanowsk P (2016) Villages and their old farmsteads are hot spots of bird diversity in agricultural landscapes. J Appl Ecol 53:1363-1372

Rupprecht CDD, Byrne JA, Gardena JG, Hero J-M (2015) Informal urban green space: a trilingual systematic review of its role or biodiversity and trends in the literature. Urban For Urban Green 14:883-908

Schlumprecht H, Bräu M (2013) Dukatenfalter [Scarce Copper] Lycaena virgaureae. In: Bräu M, Bolz R, Kolbeck H, Nunner A, Voith J, Wolf W (eds) Tagfalter in Bayern [Butterflies in Bavaria]. Eugen Ulmer, Stuttgart, pp 196-198

Schochet AB, Hung K-LJ, Holway DA (2016) Bumble bee species exhibit divergent responses to urbanisation in a Southern California landscape. Ecol Entomol 41:685-692

Seto KC, Güneralp B, Hutyrac LR (2012) Global forecasts of urban expansion to 2030 and direct impacts on biodiversity and carbon pools. PNAS 109(40):16083-16088

Shwartz A, Muratet A, Simon L, Julliard R (2013) Local and management variables outweigh landscape effects in enhancing the diversity of different taxa in a big metropolis. Biol Conserv 157:285-292 
Snep RPH, Opdam PFM, Baveco JM, WallisDeVries MF, Timmermans W, Kwaka RGM, Kuypers V (2006) How peri-urban areas can strengthen animal populations within cities: a modeling approach. Biol Conserv 127:345-355

Tolman T, Lewington R (1997) Butterflies of Britain \& Europe. Collins field guide. Harper Collins Publishers, London
Turrini T, Knop E (2015) A landscape ecology approach identifies important drivers of urban biodiversity. Glob Change Biol 21:1652-1667 